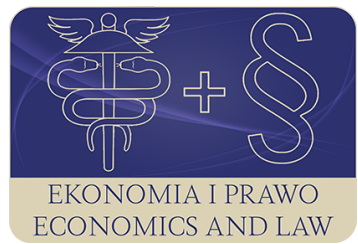

EKONOMIA I PRAWO. ECONOMICS AND LAW

Volume 16, Issue 2, June 2017

p-ISSN 1898-2255, e-ISSN 2392-1625

www.economicsandlaw.pl

ORIGINAL ARTICLE

received 13.06.2017; revised 25.06.2017; accepted 30.06.2017

Citation: Salejko-Szyszczak, I., \& Szczepaniak, M., (2017). The risk of poverty and social exclusion

in Poland in the period 2006-2015 in the comparison to the European Union countries. Ekonomia iPrawo. Ecomomics and Law, 16(2): 201-217. doi:10.12775/EiP.2017.014.

\title{
The risk of poverty and social exclusion in Poland in the period 2006-2015 in the comparison to the European Union countries
}

\author{
IWONA SALEJKO-SZYSZCZAK \\ corresponding author \\ Nicolaus Copernicus University in Toruń, Faculty of Economic Sciences and Management, \\ Department of Economics, ul. Gagarina 13a, 87-100 Toruń, Poland \\ వiwona.salejko@wp.pl

\section{MAEGORZATA SZCZEPANIAK} \\ Nicolaus Copernicus University in Toruń, Faculty of Economic Sciences and Management, \\ Department of Economics \\ $\square$ m.szczepaniak@umk.pl
}

\begin{abstract}
Motivation: The study of poverty is extremely important because of the negative impact it can have on the economy. Improving the situation of people at risk of poverty or social exclusion is one of the most important objectives of the social policy both in Poland and in the European Union. The aim is consistent with such official Polish documents as: Strategy for the Development of Human Capital 2020 National Development Strategy 2020.

Aim: The aim of the article is to assess the risk of poverty and social exclusion in Poland in the period 2006-2015, and to compare the degree of risk of poverty in Poland and other European Union countries.

Results: The study shows that the risk of poverty in Poland decreased in the analyzed period. In comparison to the EU countries, Poland made the greatest progress in reducing the risk of poverty. Dynamics of changes in reducing the risk of poverty in Poland was the highest among the EU countries. The scale of the risk of poverty in Poland in 2006 was one of the highest (with a higher risk noted only in Latvia). The situation in Po-
\end{abstract}


land in 2015 indicated that in 2015 the degree of risk of poverty was lower in Poland than in many EU countries: Portugal, Hungary, Lithuania, Latvia, Cyprus, Italy, Spain, Greece, Ireland, Estonia. In addition, the world economic crisis of 2008-2010 did not affect the risk of poverty in Poland. In most EU countries during the crisis the risk of poverty increased, however in Poland it declined. This undoubtedly allowed for improving the situation in Poland to a higher extent than in other EU countries.

Keywords: the risk of poverty; social exclusion; multidimensional measures of poverty JEL: 132; D63

\section{Introduction}

Poverty and social exclusion are major problems of the contemporary world, which concern both Poland and other EU countries. The phenomena have occurred on varying scale over the last years, often posing a threat to the existing social order.

Eliminating, or at least limiting poverty, is a primary goal of social policy, pursued not only in particular countries, but at the level of the EU as a whole. The manifestation of that objective are legal documents such as, for instance The strategy for smart and sustainable inclusive growth - Europe 2020.

The aim of the article is to evaluate the degree of poverty threat in Poland in 2006-2015, and to answer the question whether Poland's position in relation to other EU countries has improved or deteriorated over the last decade. Realization of the objective will be possible through the use of indicators such as the percentage of people who remain at risk of poverty after social transfers and social exclusion, which consists of three sub-indicators: people at risk of poverty, severely materially deprived people, and people living in households with low work intensity. Moreover, the method used in addition to qualitative analysis is quantitative analysis. The dynamics of changes of individual indicators in descriptive statistics was analyzed. The conducted study is based on data from Eurostat (2017) (survey of income and living conditions EU-SILC), which ensures its comparative character and fulfilled the requirement of using a uniform method for Poland and for the EU countries. The data covers the period 2006-2015.

\section{Definition and reasons for poverty and social exclusion}

Poverty is a complex phenomenon, which raises numerous difficulties concerning the formulation of its unambiguous definition. It is commonly perceived as a perpetual situation of low income and low consumption. However, at this point, problems appear related to the impossibility to define inadequate income level, as well as a uniform pattern of well-being, which could serve as a starting point for making comparisons (Helbich-Syrek, 2009, p. 107).

Developing the thought above, one can say that poverty is lack of sufficient material assets to live, and as a result the impossibility to obtain basic goods. 
Poverty is also a situation of human needs being unsatisfied, or satisfied to an insufficient degree. It refers to individuals whose resources are too scarce to ensure the level of living which is not lower than the minimum accepted in their country of residence. Limited poverty is destitution. Intensive poverty is poorness. Critical poverty is penury (Radziukiewicz, 2006, pp. 12-14; Helbich-Syrek, 2009, pp. 107-108).

In general, reasons for poverty can be classified as:

- personal - independent from an individual/group;

- subjective - dependent from an individual/group;

- objective - independent from the will of an individual/group (Kowalak, 2002, pp. 38-39).

Personal reasons for poverty are: disability, illness, or age. Subjective poverty results from personality traits of certain people, such as: laziness, lack of will to work and learn, or dishonesty. Objective poverty, on the other hand, is caused by rapid changes, for instance on the job market (Kowalak, 2002, pp. 38-39).

Among the reasons for poverty there are also:

- individual behaviors which are pathological in nature, and automatic inheritance of poverty (cultural reason);

- market mechanisms (liberal reason);

- blocking economic chances and development opportunities for the lover classes by the capitalist system (structural reason);

- unemployment (especially long-term);

- low-paid jobs;

- lack of social communication;

- lack of support for families and inadequate social security (Auleytner, 2002, pp. 445-446; Ruzik \& Styrc, 2006, pp. 35-36).

- The main reasons for poverty in Poland include:

- unemployment,

- low level of general income,

- decrease in real income, including pensions and retirement benefits,

- decrease in the real value of welfare benefits,

- limiting or cancelling subsidies on some consumer foods and services (Kowalak, 2002, pp. 42-43).

- Two primary categories of poverty are:

- extreme poverty (absolute);

- relative poverty (Helbich-Syrek, 2009, p. 108).

Absolute poverty is the impossibility to fulfill one's minimum needs. It concerns a relatively small portion of population, which due to their lack of income becomes lastingly marginalized. Here, a person suffering from poverty is someone whose basic needs are not satisfied sufficiently, regardless of the standard of living among the wealthier social classes. In such circumstances, a poor person is completely dependent on social welfare (a beggar, a homeless). The reason for absolute poverty are inappropriate human behaviors, such as lack 
of will to work hard, lack of professional qualifications, family life pathologies, or physical or mental disabilities (Auleytner, 2002, pp. 443-446; GUS, 2015, p. 7; Mood \& Jonsson, 2016, pp. 638-639).

Relative poverty, in turn, results from large differences in the standard of living among members of a given society, and is analyzed as a form of inequality and excessive gap between various social groups. It concerns a larger group of people, whose process of marginalization begins when their income drops below the average available in the society. Here, a poor person is someone whose income and expenses are at a mediocre level, creating conditions which are merely sufficient to survive. The reasons for thusly defined poverty is generally believed to be the functioning of a socio-economic system which does not take into account human needs, but only their usability for the economy (Auleytner, 2002, pp. 443-446; GUS, 2015, p. 7).

Using the category of relative poverty is better than addressing the phenomenon in absolute terms only, as the latter approach results in an overly narrow perception of human needs, and viewing them only in the context of physical survival of individuals, which may result in overlooking the habits and consumption patterns of a given country. This, consequently, may lead to injustice (Helbich-Syrek, 2009, p. 108).

Poverty is strictly related to the terms of material deprivation and social exclusion. People threatened with material deprivation are those who have no possibility to fulfill the needs considered basic in the European conditions (McKay, 2004, pp. 4-5; GUS, 2013, p. 41). Defining the term of social exclusion also poses numerous difficulties. It is related, among others, to changes in different economic indicators (such as minimum wage, minimum income at one's disposal, biological minimum) over time, as well as to changes in the access to the provided social services (healthcare, education, culture, accommodation quality) (Leszczyński, 2011, p. 68). The National Strategy of Social Integration for Poland defines social exclusion as: 'lack of, or limited, possibility to participate, influence and use basic public institutions and markets which should be available for everybody, especially the poor' (Leszczyński, 2011, p. 68). It is makes it impossible, or more difficult, for individuals/groups to: use public resources and social infrastructure, perform social roles, and obtain income in a decent manner. Social exclusion is viewed from the perspective of individuals or communities (such as families, trade groups, inhabitants of a given territory) (Leszczyński, 2011, p. 68).

Among the reasons for social exclusion the following should be enumerated: material poverty, unfavorable social processes, lack of education, discrimination. The basic categories of social exclusion are:

- structural exclusion - resulting from the place of residence and income below the poverty level;

- physical exclusion - resulting from age, disability, parent's level of education; 
- normative exclusion - resulting from conflicts with law, pathology, legislation concerning migrants, approach to individuals who have served a sentence (Leszczyński, 2011, p. 69).

It can be claimed that exclusion is a situation characterized by a lack of, or unequal, access to rights and institutions. When searching for relationships between poverty and social exclusion, one should notice that poverty may serve both as a cause and effect of exclusion. Thus, the two phenomena must not be considered identical, despite their correlation (Radziukiewicz, 2006, pp. 13-14).

\section{Ways to measure poverty in the European Union}

One of the objectives of Europa 2020 Strategy is decreasing the number of people threatened by poverty or social exclusion by at least 20 million by 2020 . In order to diagnose the material situation of the EU societies, and for the purpose of monitoring the realization of the strategy's goals, Eurostat provides the indicators of poverty threat indicators.

In order to compare the situation of EU member states in the field of preventing social exclusion and tackling poverty, it has become necessary to obtain coherent data and harmonized sources of information. It is possible thanks to European Union Statistics on Income and Living Condition (EU-SILC), which provides almost all basic indicators that help to evaluate the situation of Poland in terms of poverty and social exclusion in comparison to other EU countries (GUS, 2013, p. 23).

Methodical foundations of this study are defined in the European Parliament and Council Decree no 1177/2003 from 16 June 2003. The EU-SILC study was started in several member states in 2003. In Poland, it has been conducted by the Main Statistics Office of Poland since 2005.

In recent years, increasing attention has been paid to multi-dimensional approach to measuring poverty, in which the problem is viewed in a wide context, as the state of being incapable of fulfilling one's needs due to both insufficient income and lack of durable goods (Sen, 2006, p. 38; Panek, 2011, p. 40; Nolan \& Whelan, 2011). When measuring multi-dimensional poverty, the factors taken into consideration include, for instance, limited or no access to healthcare, education, culture, or weakening of social bonds (overall poverty). An example of such a measurement is a MPI synthetic measure (Multidimensional Poverty Index), calculated by UNDP since 2010. However, measuring poverty in multi-dimensional terms by means of one synthetic measure may raise doubts concerning simplifications and generalizations of the measurement conducted (Ravallion, 2011, p. 246) (scheme 1).

The study (due to difficulties with measuring many income-independent factors influencing the degree of poverty) made use of measures based on income-related factors. The primary synthetic measure taken into consideration is the at risk of poverty or social exclusion rate (AROPE) determined for the pur- 
pose of monitoring the realization of objectives of Europe 2020 Strategy. It is calculated on the basis of three partial sub-indicators:

- at-risk of poverty rate after social transfers (ARPR);

- severe material deprivation rate;

- the rate of people living in households with very low work intensity.

According to the method agreed upon (GUS, Eurostat) the people considered to be at risk of poverty are those who live in households whose disposable income is lower than the threshold set at the level of $60 \%$ of the median of income in a given country ${ }^{1}$. The indicator is criticized mostly due to the fact that making use of country-based income values generally limits the comparability among countries. Although Eurostat calculates the thresholds of income-related poverty in particular member states according to purchasing power parity, $60 \%$ of the median of income in a poor country means a completely different material situation than $60 \%$ of the median of income in a rich one, which makes the measure not objective. It is worth at this point to demonstrate the high diversity of the poverty threshold in particular states of the EU (chart 1).

When calculating the severe material deprivation indicator, the factor taken into consideration is lack of possibility to fulfill the needs which are considered basic in the European conditions. The rate of people at risk of severe material deprivation is defined as the percentage of people within households who declare being unable, due to financial reasons, to fulfill at least 4 out of 9 needs listed in Table 1.

The main advantage of the material deprivation rate is its greater comparability among countries than the ARPR rate offers in its present form when used as the basic indicator in the European Union. However, the measure should be considered subjective, since the evaluation of the degree of satisfaction of needs is conducted by the studied individuals themselves, which may undoubtedly lead to problems with comparative analysis, due to changes in the perception of certain needs.

Low work intensity indicator takes into account the factor of unemployment as the reason for poverty. The indicator also indirectly illustrates the issue of social exclusion. It concerns people aged 0 to 59, living in households characterized by very low work intensity, which means a situation when in the past year adults worked for less than $20 \%$ of their total work potential.

Comparative studies on poverty risk in Poland in relation to other EU countries have been conducted based on the analysis of the abovementioned factors in Poland and in the EU countries. The additional indicators: the indicator of poverty or social exclusion risk due to age or sex, as well as before and after

${ }^{1}$ The basis of measurement is the income at disposal, understood as the sum of all annual net income (after subtracting the advances on income tax, property tax, social security and health insurance) of all household dwellers. In order to eliminate the impact of the household's demographic composition, a weight of $l$ is assigned to the first person over 14 in the household, with a weight of 0.5 assigned to each next person, and a weight of 0.3 to each child under 14 years of age. 
social transfers (to show how the transfers affect the determination of the poverty threshold) were used in order to conduct in-depth studies.

\section{Changes in the poverty risk in Poland in comparison to other European Union countries}

The main indicator which should be taken into account while evaluating the change in poverty risk in Poland in comparison to other EU countries is At risk of poverty or social exclusion rate.

In 2015 in the European Union 23.7\% of population were at risk of poverty or social exclusion. At risk of poverty or social exclusion rate has dropped slightly in comparison to 2006, when it was $25.3 \%$. The countries where the lowest rates were noted in 2015 were the Czech Republic, Sweden and Holland (14.0-16.4\%). The countries whose position at that time was the most difficult were Greece, Romania and Bulgaria, where over 35\% of population were at risk of poverty or social exclusion. The AROPE rate in Poland in 2015 was 23.4\%, and was slightly lower than the European average. In 2006-2015 the value At risk of poverty or social exclusion rate in Poland dropped by $16.1 \mathrm{pp}$. Comparing it to other EU countries, it can be noticed that only in Bulgaria was the drop bigger (20 pp). The country, however, still held the last position in the EU in terms of risk of poverty or social exclusion (Table 2).

When evaluating the situation of Poland in comparison to other EU countries in 2006-2015 making use of at risk of poverty or social exclusion rate, one can notice that its position was improving year by year, and that the indicator's value was nearing the EU average. In the beginning, the difference between its values in Poland and in the EU was 14.2 pp, whereas in 2015 the situation in Poland was better than in the EU as a whole. In Poland, the value of that indicator then was 23.4\%, whereas for the European Union it oscillated around $23.7 \%$ (chart 2). The average annual pace of decrease in the risk of poverty or social exclusion was $6.3 \%$ in the period of 2006-2015. No other EU country has managed to achieve such high dynamics of positive changes (own calculations based on Eurostat (2017)).

The most disturbing fact seems to be that, both in 2006 and 2015, children were the social group which was most threatened by poverty or social exclusion in Poland and in the EU as a whole. During the last decade, the situation in Poland has improved significantly. The risk of poverty or social exclusion indicator for children has dropped from $41.3 \%$ to $26.6 \%$, with the indicator being generally lower for all the analyzed age groups. In the working age group, the value of risk of poverty or social exclusion indicator has dropped from $40.2 \%$ to 24.1 and in 2015 was slightly lower than the average for the EU-28 countries. An improvement exceeding the average for the EU has also occurred in the senior citizens group. In Poland, at risk of poverty or social exclusion rate has dropped from $32.5 \%$ to $17 \%$, decreasing by almost half (Table 3 ). It was not, however, all EU countries that noted higher a threat of poverty among children in 2015. 
A better situation than in Poland (and a lower risk in the children group than a country in general) was observed in Sweden, Finland, Slovenia, Estonia, Germany and Denmark. The worst situation was noted in Bulgaria and Romania, where in $201544 \%$ and $47 \%$ of children, respectively, were at risk of poverty or social exclusion. The group where the poverty risk indicator was the least varied were the professionally active, as it oscillated between $14 \%$ to $39 \%$ of population aged between 18 and 64. The leaders in this respect were the Czech Republic (14\%) and Sweden (16\%). The worst situation was in Greece (39\%), Romania (36\%) and Bulgaria (37\%). The senior citizens group was marked by even greater diversity, amounting to 8\% of population in Luxembourg, 9\% in France, and 6\% in Holland, but to as many as 52\% of people aged over 65 in Bulgaria threatened by poverty (Eurostat, 2017).

Taking into account the at risk of poverty or social exclusion rate according to sex, it should be noticed that over the decade the situation has changed more profoundly among women than men, both in Poland and in the EU (Table 4). The phenomenon appears in accordance with labor market data, which indicates a growing share of women in the total employment figures. In addition, it is worth noting that the situation in Poland in 2015 was better than in the EU countries' average.

Other indicators allowing for evaluation of poverty risk in Poland in comparison to other EU countries are: at risk of poverty rate (before and after social transfers), severe material deprivation indicator, and low work intensity indicator.

The factor which is arguably worth emphasizing at this point is a significantly lower value of the at risk of poverty rate after social transfers in comparison to the general poverty or social exclusion risk in each of the EU countries. After taking into account social transfers, in 2015 the lowest numbers of people at risk of poverty were noted in: the Czech Republic (9.7\%), Holland (11.6\%) and Denmark (12.2\%), and the highest ones in Romania (25.4\%). In Poland, the indicator in 2015 was $17.6 \%$, and was lower by 1.5 pp than the one from 2006. In each of the countries the poverty risk indicator was higher when no social transfers were taken into account. In Poland, throughout the decade the difference has decreased from $9.5 \mathrm{pp}$ to $5.3 \mathrm{pp}$, which may serve as evidence of a decreasing number of social transfers in the process of tackling poverty risk. Apart from that, in comparison to the EU average, the poverty risk indicator has remained at a comparable level in Poland (17.6\%) and in EU-27 (17.3\%). The poverty risk indicator without considering social transfers was lower in Poland (22.9\%) than in the EU (26\%) (Table 5).

In 2015 the rate of people living in households of low work intensity in Poland was $6.9 \%$ (in the EU the rate was 10.6\%), and it decreased by $3.2 \mathrm{pp}$ in comparison to 2006 (in the EU there was an increase by $0.8 \mathrm{pp}$ ). In 2015, the best situation in terms on this indicator was noted in Luxembourg (5.7\%) and Sweden $(5.8 \%)$. The highest rate of households of low work intensity was observed in 2015 in Ireland (19.2\%) and Greece (16.8\%) (Table 6). 
In 2008-2016 the rate of people living in households of low work intensity in the European Union exceeded the value for Poland, which indicates a better situation of Poland in comparison to other EU countries. It was only in 2007 that the value of this indicator for Poland (10.1\%) was slightly higher than the EU average (9.8\%). Poland has also experienced a significant drop in the percentage of people living in households of low work intensity in the first years of the studied period, and a stabilization of the rate at the level around 7\% in 2007-2015. The EU average was between $9.2 \%$ and $11.2 \%$ (chart 3).

The indicator of severe material deprivation points to Poland's difficult situation in comparison to other EU countries during the first years of the studied period, when its value for Poland was almost a double of the EU average. In 2015 the rate of people at risk of severe material deprivation was the lowest in Luxembourg (2\%) and Finland (2.2\%), and the highest in Bulgaria (34.2\%), Romania (22.7\%), and Greece (22.2\%). In the case of Poland, $8.1 \%$ of population were unable to fulfill at least 4 out of 9 needs in question, which was only $0.1 \%$ more than in the EU 27. In Poland, there has been one of the most noticeable drops in the number of people at risk of severe material deprivation in 2007-2015, which was $14.2 \mathrm{pp}$. A largest decrease in the number of people at risk of severe material deprivation during the studied period was noticed only in Bulgaria (23.4 pp) and Romania (15.3 pp) (Table 6).

\section{Conclusion}

The conducted study allows for the conclusion that not only has the risk of poverty or social exclusion in Poland decreased in the period of 2006-2015, but Poland's position in relation to other European Union countries has improved as well. Poland is a country where the dynamics of positive changes in terms of poverty was the highest.

A detailed analysis of poverty risk has shown that the situation of women in Poland has improved significantly, yet there is still a relatively high risk of poverty concerning children and youth. Moreover, in Poland social transfers appear to be relatively ineffective in terms of decreasing poverty. It is predicted that the situation may change after 2016, due to the start of 500+ government program.

Subject literature also points to the need to study the relations and dependencies between particular indicators used for monitoring the realization of the objectives connected with limiting poverty (Ayllon \& Gabos, 2017, p. 1026), which is undoubtedly important from the point of view of social policy, not only in Poland, but throughout the European Union.

The study findings, however, raise the question of identification of the factors which could have influence on the changes observed in Poland. Thus, the next stage of work is meant to include an in-depth analysis of the studied phenomenon. The factors which may have great impact on the decrease in risk of poverty or social exclusion are, among others, changes in the labor market (especially an 
increased women's share in the total employment, changes in the salary levels, changes in work efficiency, or decreased unemployment), migrations, intensified foreign trade, and the dynamics of developmental processes of the economy. The described problems are also strictly related to the state's redistributive policy. Hence it also seems essential to conduct an analysis of social expenses, transfers and taxes.

\section{References}

Auleytner, J. (2002). Polityka spoteczna, czyli ujarzmianie chaosu socjalnego. Warszawa: Wydawnictwo Wyższej Szkoły Pedagogicznej Towarzystwa Wiedzy Powszechnej.

Ayllon, S., Gabos, A. (2017). The interrelationships between the Europe 2020 poverty and social exclusion indicators. Social Indicators Research, 130(3). doi:10.1007/s11205-015-1212-2.

Eurostat. (2017). Retrieved 26.03.2017 from http://ec.europa.eu/eurostat.

GUS. (2013). Ubóstwo w Polsce w świetle badań GUS. Retrieved 26.03.2017 from http: //stat.gov.pl.

GUS. (2015). Ubóstwo w Polsce w latach 2013 i 2014. Retrieved 26.03.2017 from http://stat.gov.pl.

Kowalak, T. (2002). Polityka spoteczna. Wybrane zagadnienia. Białystok: Wydawnictwo Wyższej Szkoły Ekonomicznej.

Helbich-Syrek, A., (2009). Polityka wobec ubóstwa. In O. Kowalczyk, \& S. Kamiński (Eds.), Wymiary polityki spotecznej. Wrocław: Wydawnictwo UE we Wrocławiu.

Leszczyński, M. (2011). Bezpieczeństwo spoteczne Polaków wobec wyzwań XXI wieku. Warszawa: Wydawnictwo Zarządzanie Bezpieczeństwem.

McKay, S. (2004). Poverty or preference: what do 'consensual deprivation indicators’ really measure? Fiscal Studies, 25(2). doi:10.1111/j.1475-5890.2004. tb00102.x.

Mood, C., \& Jonsson, J.O. (2016). The social consequences of poverty: an empirical test on longitudinal data. Social Indicators Research, 127(2). doi:10.1007/ s11205-015-0983-9.

Nolan, B., \& Whelan, C.T. (2011). Poverty and deprivation in Europe. Oxford: Oxford University Press.

Panek, T. (2011). Ubóstwo, wykluczenie spoteczne i nierówności. Teoria i praktyka pomiaru. Warszawa: Oficyna Wydawnicza SGH.

Radziukiewicz, M. (2006). Zasięg ubóstwa w Polsce. Warszawa: PWE.

Ravallion, M. (2011). On multidimensional indices of poverty. The Journal of Economic Inequality, 9(2). doi:10.1007/s10888-011-9173-4.

Ruzik, A., \& Styrc, M. (2006). Przeciwdziałać drodze od ubóstwa do wykluczenia społecznego. Polityka Spoteczna, 3(384).

Sen, A. (2006). Conceptualizing and measuring poverty. In: D. Grusky, \& R. Kanbur (Eds.), Poverty and inequality. Stanford: Stanford University Press. 


\section{Acknowledgements}

Author contributions: authors have given an approval to the final version of the article. Authors contributed to this work equally.

Note: the results of this study were presented at 9th International Conference on Applied Economics Contemporary issues in Economy (Toruń, June 22-23, Torun, Poland). 


\section{Appendix}

Table 1.

Declared areas (needs) taken into account while calculating the severe material deprivation rate

\begin{tabular}{|c|c|c|c|}
\hline No. & Need & $\begin{array}{l}\text { Income based } \\
\text { criterion }\end{array}$ & $\begin{array}{l}\text { Criterion: lack } \\
\text { of durable goods }\end{array}$ \\
\hline 1 & $\begin{array}{l}\text { declaring lack of funds to pay for a week-long holiday trip for all house- } \\
\text { hold dwellers once a year }\end{array}$ & $\mathrm{x}$ & - \\
\hline 2 & $\begin{array}{l}\text { declaring lack of possibility to eat meat or fish (or their vegetarian equiv- } \\
\text { alent) every second day }\end{array}$ & $\mathrm{x}$ & - \\
\hline 3 & declaring lack of possibility to heat the apartment according to needs & $\mathrm{x}$ & - \\
\hline 4 & $\begin{array}{l}\text { lack of possibility to cover an unexpected expense (amounting } \\
\text { to the equivalent of a monthly value of the relative poverty threshold for } \\
\text { a given country) }\end{array}$ & $\mathrm{x}$ & - \\
\hline 5 & overdue liabilities related to rent, instalments and loans & $\mathrm{x}$ & - \\
\hline 6 & lack of a color TV set in the household & $\mathrm{x}$ & $\mathrm{x}$ \\
\hline 7 & lack of a car in the household & $\mathrm{x}$ & $\mathrm{x}$ \\
\hline 8 & lack of a washing machine in the household & $\mathrm{x}$ & $\mathrm{x}$ \\
\hline 9 & lack of a telephone in the household (landline or cell phone) & $\mathrm{x}$ & $\mathrm{x}$ \\
\hline
\end{tabular}

Source: own preparation based on Eurostat (2017).

Table 2.

At risk of poverty or social exclusion rate in the EU countries in 2006 and 2015 (in \%)

\begin{tabular}{|c|c|c|c|c|c|}
\hline Country & 2006 & Position in 2006 & 2015 & Position in 2015 & Change \\
\hline EU-27 & 25.3 & - & 23.7 & - & -1.6 \\
\hline Austria & 17.8 & 7 & 18.3 & 7 & 0.5 \\
\hline Belgium & 21.5 & 12 & 21.1 & 12 & -0.4 \\
\hline Bulgaria & 61.3 & 28 & 41.3 & 28 & -20 \\
\hline Croatia* & 31.1 & 22 & 29.1 & 23 & -3.0 \\
\hline Cyprus & 25.4 & 18 & 28.9 & 22 & 3.5 \\
\hline Czech Republic & 18.0 & 8 & 14.0 & 1 & -4.0 \\
\hline Denmark & 16.7 & 4 & 17.7 & 5 & 1.0 \\
\hline Estonia & 22.0 & 13 & 24.2 & 16 & 2.2 \\
\hline Finland & 17.1 & 5 & 16.8 & 4 & -0.3 \\
\hline France & 18.8 & 9 & 17.7 & 6 & -1.1 \\
\hline Germany & 20.2 & 11 & 20.0 & 11 & -0.2 \\
\hline Great Britain & 23.7 & 15 & 23.5 & 15 & -0.2 \\
\hline Greece & 29.3 & 21 & 35.7 & 26 & 6.4 \\
\hline Holland & 16.0 & 1 & 16.4 & 3 & 0.4 \\
\hline Hungary & 31.4 & 23 & 28.2 & 19 & -3.2 \\
\hline Ireland & 23.3 & 14 & 26.0 & 17 & 2.7 \\
\hline Italy & 25.9 & 19 & 28.7 & 21 & 2.8 \\
\hline Latvia & 42.2 & 26 & 30.9 & 25 & -11.3 \\
\hline Lithuania & 35.9 & 24 & 29.3 & 24 & -6.6 \\
\hline Luxembourg & 16.5 & 3 & 18.5 & 9 & 2.0 \\
\hline Malta & 19.5 & 10 & 22.4 & 13 & 2.9 \\
\hline
\end{tabular}




\begin{tabular}{lcccrr}
\hline \multicolumn{1}{c}{ Country } & 2006 & Position in 2006 & 2015 & Position in 2015 & Change \\
\hline Poland & 39.5 & 25 & 23.4 & 14 & -16.1 \\
Portugal & 25.0 & 17 & 26.6 & 18 & 1.6 \\
Romania** & 47.0 & 27 & 37.4 & 27 & -9.6 \\
Slovakia & 26.7 & 20 & 18.4 & 8 & -8.3 \\
Slovenia & 17.1 & 5 & 19.2 & 10 & 2.1 \\
Spain & 24.0 & 16 & 28.6 & 20 & 4.6 \\
Sweden & 16.3 & 2 & 16.0 & 2 & -0.3 \\
\hline
\end{tabular}

Note:

*** — the indicator values for Croatia and Romania, due to limited data availability, were provided for 2010 and 2007 , respectively.

Source: own preparation based on Eurostat (2017).

Table 3.

At risk of poverty or social exclusion rate in Poland and the EU average according to age in 2006 and 2015 (in \%)

\begin{tabular}{lcccccccc}
\hline \multirow{2}{*}{ Country } & \multicolumn{2}{c}{ Total } & & \multicolumn{2}{c}{ Children $(0-17$ years $)$} & $\begin{array}{c}\text { Working age population } \\
(18-64 \text { years })\end{array}$ & \multicolumn{2}{c}{ Senior citizens (65+) } \\
\cline { 2 - 9 } & 2006 & 2015 & 2006 & 2015 & 2006 & 2015 & 2006 & 2015 \\
\hline Poland & 39.5 & 23.4 & 41.3 & 26.6 & 40.2 & 24.1 & 32.5 & 17.0 \\
EU-27 & 25.3 & 23.7 & 27.2 & 26.9 & 24.8 & 24.7 & 24.7 & 17.4 \\
\hline
\end{tabular}

Source: own preparation based on Eurostat (2017).

Table 4.

At risk of poverty or social exclusion rate in Poland and in the EU-27 average according to sex in 2006 and 2015 (in \%)

\begin{tabular}{lrrrrrc}
\hline \multirow{2}{*}{ Country } & \multicolumn{2}{c}{ Total } & \multicolumn{2}{c}{ Men } & \multicolumn{2}{c}{ Women } \\
\cline { 2 - 7 } & 2006 & 2015 & 2006 & 2015 & 2006 & 2015 \\
\hline Poland & 39.5 & 23.4 & 39.0 & 23.7 & 40.0 & 23.2 \\
EU-27 & 25.3 & 23.7 & 23.9 & 23.0 & 26.6 & 24.4 \\
\hline
\end{tabular}

Source: own preparation based on Eurostat (2017). 
Table 5 .

Risk of poverty or social exclusion indicator before and after taking into account social transfers in the EU countries in 2006 and 2015 (in \%)

\begin{tabular}{|c|c|c|c|c|c|c|c|c|}
\hline \multirow[t]{2}{*}{ Country } & \multicolumn{3}{|c|}{$\begin{array}{c}\text { At risk of poverty or social exclusion } \\
\text { rate after social transfers }\end{array}$} & \multicolumn{3}{|c|}{$\begin{array}{l}\text { At risk of poverty or social exclusion } \\
\text { rate before social transfers }\end{array}$} & \multicolumn{2}{|c|}{ Difference } \\
\hline & 2006 & 2015 & Change & 2006 & 2015 & Change & 2006 & 2015 \\
\hline EU 27 & 16.5 & 17.3 & 0.8 & 26.1 & 26.0 & -0.1 & 9.6 & 8.7 \\
\hline Austria & 12.6 & 13.9 & 1.3 & 25.1 & 25.6 & 0.5 & 12.5 & 11.7 \\
\hline Belgium & 14.7 & 14.9 & 0.2 & 26.8 & 26.7 & -0.1 & 12.1 & 11.8 \\
\hline Bulgaria & 18.4 & 22 & 3.6 & 24.7 & 28.4 & 3.7 & 6.3 & 6.4 \\
\hline Croatia & - & 20.0 & - & 30.0 & 31.0 & 1.0 & - & 11.0 \\
\hline Cyprus & 15.6 & 16.2 & 0.6 & 21.6 & 25.4 & 3.8 & 6.0 & 9.2 \\
\hline Czech Republic & 9.9 & 9.7 & -0.2 & 21.6 & 16.8 & -4.8 & 11.7 & 7.1 \\
\hline Denmark & 11.7 & 12.2 & 0.5 & 28.0 & 25.8 & -2.2 & 16.3 & 13.6 \\
\hline Estonia & 18.3 & 21.6 & 3.3 & 24.6 & 27.8 & 3.2 & 6.3 & 6.2 \\
\hline Finland & 12.6 & 12.4 & -0.2 & 28.6 & 26.8 & -1.8 & 16.0 & 14.4 \\
\hline France & 13.2 & 13.6 & 0.4 & 24.9 & 23.9 & -1.0 & 11.7 & 10.3 \\
\hline Germany & 12.5 & 16.7 & 4.2 & 25.7 & 25.1 & -0.6 & 13.2 & 8.4 \\
\hline Great Britain & 19.0 & 16.7 & -2.3 & 30.1 & 29.2 & -0.9 & 11.1 & 12.5 \\
\hline Greece & 20.5 & 21.4 & 0.9 & 23.4 & 25.5 & 2.1 & 2.9 & 4.1 \\
\hline Holland & 9.7 & 11.6 & 1.9 & 21.0 & 22.3 & 1.3 & 11.3 & 10.7 \\
\hline Hungary & 15.9 & 14.9 & -1.0 & 29.6 & 25.7 & -3.9 & 13.7 & 10.8 \\
\hline Ireland & 18.5 & 16.3 & -2.2 & 32.8 & 36.2 & 3.4 & 14.3 & 19.9 \\
\hline Italy & 19.3 & 19.9 & 0.6 & 23.7 & 25.4 & 1.7 & 4.4 & 5.5 \\
\hline Latvia & 23.5 & 22.5 & -1.0 & 28.0 & 27.3 & -0.7 & 4.5 & 4.8 \\
\hline Lithuania & 20.0 & 22.2 & 2.2 & 26.6 & 28.6 & 2.0 & 6.6 & 6.4 \\
\hline Luxembourg & 14.1 & 15.3 & 1.2 & 23.6 & 27.2 & 3.6 & 9.5 & 11.9 \\
\hline Malta & 14.2 & 16.3 & 2.1 & 21.3 & 23.7 & 2.4 & 7.1 & 7.4 \\
\hline Poland & 19.1 & 17.6 & -1.5 & 28.6 & 22.9 & -5.7 & 9.5 & 5.3 \\
\hline Portugal & 18.5 & 19.5 & 1.0 & 25.1 & 26.4 & 1.3 & 6.6 & 6.9 \\
\hline Romania & - & 25.4 & - & 31.5 & 29.3 & -2.2 & 31.5 & 3.9 \\
\hline Slovakia & 11.6 & 12.3 & 0.7 & 28.6 & 22.9 & -5.7 & 17.0 & 10.6 \\
\hline Slovenia & 11.6 & 14.3 & 2.7 & 24.2 & 24.8 & 0.6 & 12.6 & 10.5 \\
\hline Spain & 20.3 & 22.1 & 1.8 & 24.6 & 30.1 & 5.5 & 4.3 & 8.0 \\
\hline Sweden & 12.3 & 14.5 & 2.2 & 29.0 & 26.9 & -2.1 & 16.7 & 12.4 \\
\hline
\end{tabular}

Source: own preparation based on Eurostat (2017). 
Table 6.

Rate of people living in households of low work intensity and the rate of people at risk of severe material deprivation in the EU countries in 2007 and 2015 (in \%)

\begin{tabular}{|c|c|c|c|c|c|c|}
\hline \multirow[t]{2}{*}{ Country } & \multicolumn{3}{|c|}{$\begin{array}{c}\text { The rate of people living in households of low } \\
\text { work intensity }\end{array}$} & \multicolumn{3}{|c|}{$\begin{array}{l}\text { The rate of people threatened by severe } \\
\text { material deprivation }\end{array}$} \\
\hline & 2007 & 2015 & Change & 2007 & 2015 & Change \\
\hline EU 27 & 9.8 & 10.6 & 0.8 & 9.2 & 8.0 & -1.2 \\
\hline Austria & 8.2 & 8.2 & - & 3.3 & 3.6 & 0.3 \\
\hline Belgium & 13.8 & 14.9 & 1.1 & 5.7 & 5.8 & 0.1 \\
\hline Bulgaria & 16.0 & 11.6 & -4.4 & 57.6 & 34.2 & -23.4 \\
\hline Croatia & - & 14.4 & - & - & 13.7 & - \\
\hline Cyprus & 3.7 & 10.9 & 7.2 & 13.3 & 15.4 & 2.1 \\
\hline Czech Republic & 8.6 & 6.8 & -1.8 & 7.4 & 5.6 & -1.8 \\
\hline Denmark & 10.1 & 11.6 & 1.5 & 3.3 & 3.7 & 0.4 \\
\hline Estonia & 6.2 & 6.6 & 0.4 & 5.6 & 4.5 & -1.1 \\
\hline Finland & 8.8 & 10.8 & 2.0 & 3.6 & 2.2 & -1.4 \\
\hline France & 9.6 & 8.6 & -1.0 & 4.7 & 4.5 & -0.2 \\
\hline Germany & 11.5 & 9.8 & -1.7 & 4.8 & 4.4 & -0.4 \\
\hline Great Britain & 10.4 & 11.9 & 1.5 & 4.2 & 6.1 & 1.9 \\
\hline Greece & 8.1 & 16.8 & 8.7 & 11.5 & 22.2 & 10.7 \\
\hline Holland & 9.7 & 10.2 & 0.5 & 1.7 & 2.6 & 0.9 \\
\hline Hungary & 11.3 & 9.4 & -1.9 & 19.9 & 19.4 & -0.5 \\
\hline Ireland & 14.3 & 19.2 & 4.9 & 4.5 & 7.5 & 3.0 \\
\hline Italy & - & 11.7 & - & 7.0 & 11.5 & 4.5 \\
\hline Latvia & 6.2 & 7.8 & 1.6 & 24 & 16.4 & -7.6 \\
\hline Lithuania & 6.4 & 9.2 & 2.8 & 16.6 & 13.9 & -2.7 \\
\hline Luxembourg & 5.0 & 5.7 & 0.7 & 0.8 & 2.0 & 1.2 \\
\hline Malta & 9.6 & 9.2 & -0.4 & 4.4 & 8.1 & 3.7 \\
\hline Poland & 10.1 & 6.9 & -3.2 & 22.3 & 8.1 & -14.2 \\
\hline Portugal & 7.2 & 10.9 & 3.7 & 9.6 & 9.6 & - \\
\hline Romania & 9.9 & 7.9 & -2.0 & 38 & 22.7 & -15.3 \\
\hline Slovakia & 6.4 & 7.1 & 0.7 & 13.7 & 9.0 & -4.7 \\
\hline Slovenia & 7.3 & 7.4 & 0.1 & 5.1 & 5.8 & 0.7 \\
\hline Spain & 6.8 & 15.4 & 8.6 & 3.5 & 6.4 & 2.9 \\
\hline Sweden & 6.0 & 5.8 & -0.2 & 2.2 & 0.7 & -1.5 \\
\hline
\end{tabular}

Source: own preparation based on Eurostat (2017). 
Scheme 1 .

Ways of measuring poverty

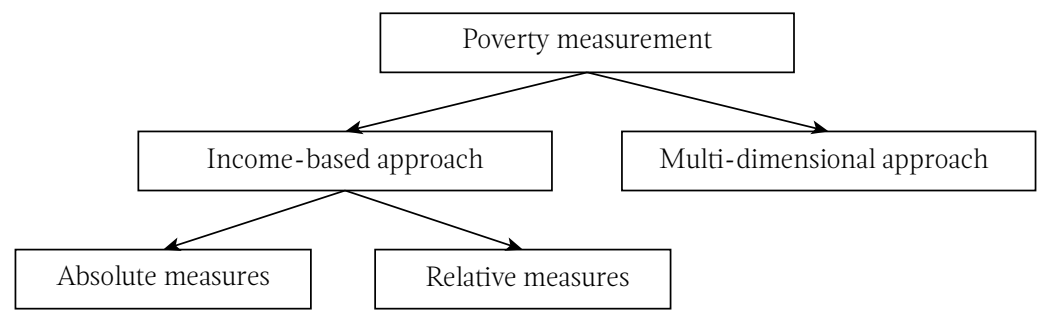

Source: own preparation.

Chart 1.

At risk of poverty threshold (60\% of median equivalised income) in EU states in 2006 and 2015

25000

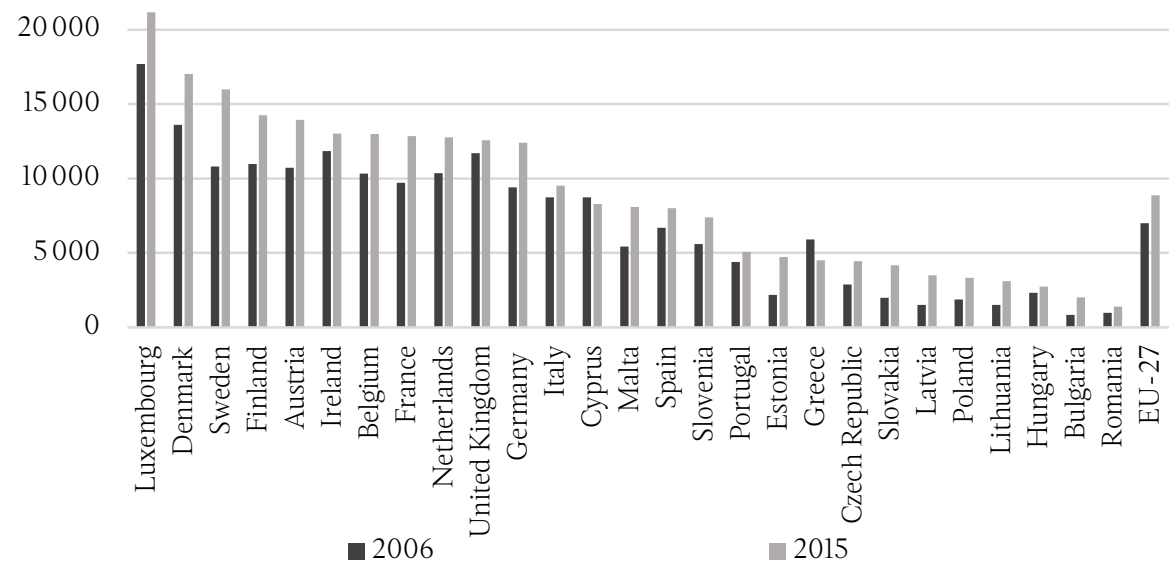

Note:

For Romania, the data 2007. The countries were ordered according to the value of $60 \%$ of median equivalised income.

Source: own preparation based on Eurostat (2017). 
Chart 3.

The rate of people living in households of low work intensity (in \%)

45

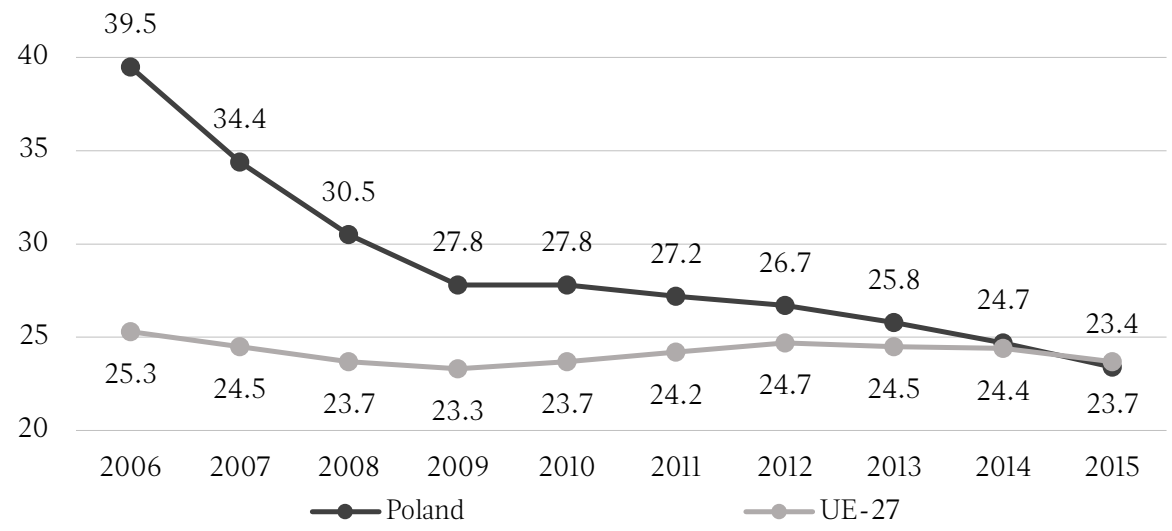

Source: own preparation based on Eurostat (2017).

Chart 2.

The dynamics of changes in at risk of poverty or social exclusion rate in Poland and in the EU countries in 2006-2015 (in \%)

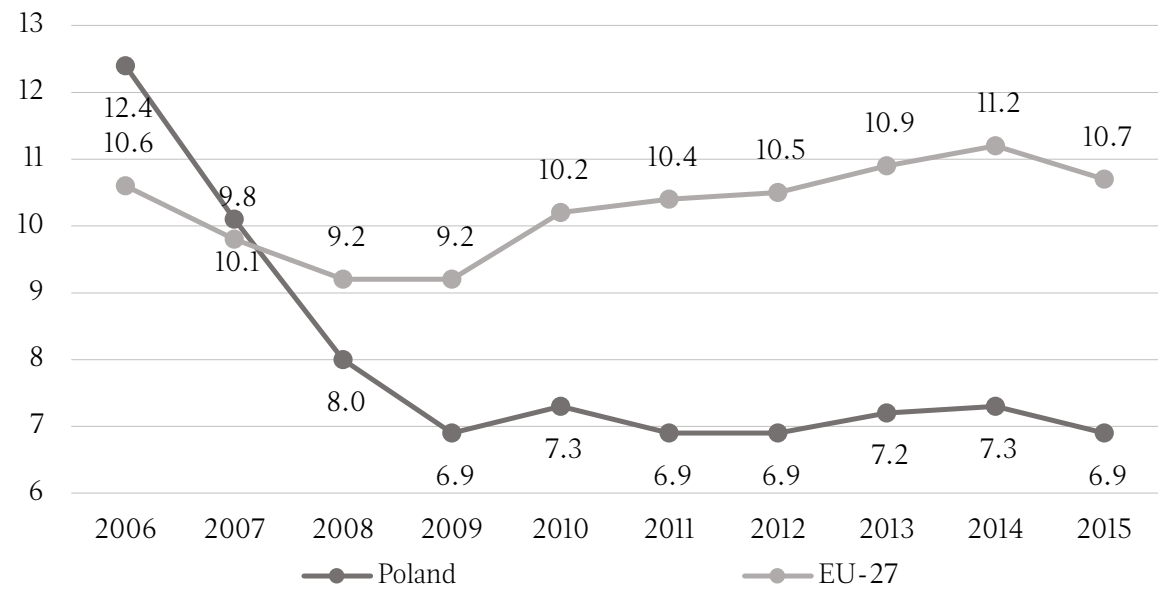

Source: own preparation based on Eurostat (2017). 
